\title{
Researching direct action against carbon emissions: A digital ethnography of climate agency
}

\author{
R. Pearse and J. Goodman \\ University of Technology, Sydney \\ S. Rosewarne \\ University of Sydney
}

\begin{abstract}
Global warming poses very directly the question of human agency. In this video ethnography of climate agency we explore dimensions of subjectivity in climate activism. Through a longitudinal study we track activist strategising as a reflexive process of creating climate agency. Activist reflection is presented as a balance between involvement and detachment, and analysed drawing on videoed interviews and on our own participation in organisations and events. Visual artefacts are deployed to deepen insights into the interview process, and into the contexts for climate action. In terms of the analysis, there are three themes. First we look at trajectories - how people come to identify with the climate movement and engage in its direct action wing. Second, we explore the hopes and fears of climate activists in the face of profound challenges. Third, we address political antidotes, and the role of direct action in precipitating large-scale systemic change. Across these themes there is much diversity and debate: what unifies is a common engagement in the broad field of direct climate action. This visual documentation helps us reflect on the conflicts and possibilities that thereby arise in contexts of climate activist praxis.
\end{abstract}

Because you can look at something and go "That was something nice that we created", or maybe "it wasn't nice, but we tried" ' [laughs].

(Wells 2008)

Social agency is by necessity caught between involvement in the daily troubles of society and the need to gain an external perspective, in order to act on it. Involvement is necessary for the insights it allows into social experiences; detachment is necessary to acquire a perspective on these experiences, to enable social agency (Elias 1956, 2007). The responsibility of the sociologist - indeed of anyone involved in social action - is to bridge these worlds, to create the imagination needed for transformative agendas and visions, enabling us to become subjects of history, rather than its objects (Mills 1959/2000). The challenge is to produce grounded explanations in dialogue with subjective or affective knowledge (Juris 2008). Indeed, using embedded explanations to produce normative claims is central to any possibility of a collective social movement 'subjectivation' (Touraine 1995). The resulting practice-theory exchange, or praxis, is an important site in the production of emancipatory knowledge, to transform social relations (Johnston \& Goodman 2006). This article explores how digital ethnography may help us explore this process, focusing on the current intensifying crisis of global warming. 
Global warming poses very directly the question of human agency in the face of crisis, writ large on a global scale. In his writings on 'Involvement and Detachment', Norbert Elias addresses exactly this nexus, retelling Edgar Allen Poe's story of two mariners caught in a whirlpool created by their sinking ship (2007). One mariner is so involved in the crisis that he panics and flails around despairingly. The other mariner is able to reflect critically on their situation, and realises that a wooden barrel appears to be falling more slowly into the vortex. The second mariner grabs the barrel and floats free; the first mariner is drowned. The metaphor nicely encapsulates the global warming crisis, where engagement with the intensity of the crisis can produce a politics of avoidance, a variant of what Ulrich Beck calls 'apocalypse blindness' (Beck 1992). Here, the involvement/detachment dilemma is cast in sharp relief. We argue that the potential for climate agency comes from precisely this combined engagement with the intensity of the crisis and an ability to reflect on how to act on society to address the crisis (Melucci 1996b).

Climate crisis and climate agency are, in this way, locked into a dialectical struggle. This characterisation is particularly evident where we distinguish crisis as a product of the internal contradictions of society from an externally imposed catastrophe. Global warming is a product of human society, in its current capitalist model it is not an accident of natural history. Society causes warming, and as such society can solve it. The question, though, is how? In the current era, finding answers to this question is a key priority for engaged sociological inquiry. How are we to investigate global warming in a way that engages both with the science of climate change and the social process of acting on it? Notwithstanding controversy over the various diagnoses of global warming, it is possible to routinely access the science of global warming; but how are we to arrive at meaningful accounts of climate agency?

In debates about climate change there is a strong tendency to configure climate action as being first and foremost grounded in science, rather than in values or political ideologies (e.g. Low 2010). This rationalist bent runs the risk of missing the generative potential of affect, values, norms and of political vision in the process of collective mobilisation. To address agency we need to become as far as possible directly engaged with the embodied process of climate action, as a precondition for framing climate science and for gaining the required 
transformative imagination. Since 2007 we have been exploring how to do this, developing a research process that would approximate to the requirement that, as researchers, we need to generate data that involves us, and as far as possible our readers, in questions of climate agency, whilst at the same time offering a perspective on how that agency may be developed.

In doing so we arrive at involvement/detachment as a dialectical relationship, albeit with caution. We are conscious of its limits, as a proxy for reified relations between realism and idealism (Rojek 1986); we are also conscious of its radical openness. Elias, for instance, supplies no clear methodological approach, save the assertion that history must be studied as a relatively open process (ibid.). Our premise, though, is that social agency is best analysed through this lens, as a struggle for leverage over socio-systemic forces. We also arrive at an ethnographic method where dimensions of climate agency are addressed with participations in the climate change movement. As researchers and participants in the movement we begin from the assumption that only a reflexive method of inquiry, of this sort, can embed the needed dynamics of involvement and detachment (Steier 1991). We seek to avoid academic ‘self fascination', and instead explore reflexivity as activist practice, as much as research method (Bourdieu \& Wacquant 1992, p. 72; Riach 2009). This two-pronged approach, we believe, allows us to look at reflexivity-in-practice, apparent in both the participants’ narratives and our methodology and interpretation (Riach 2009).

In what follows we outline key dimensions of the research approach. We then use a series of short videoed excerpts, and in-text discussion, to introduce the concept of direct climate action in Australia. We then analyse the activist accounts, focusing on three main themes, with each theme prefaced by videoed excerpts of the interviews. In the first theme we analyse activist trajectories - how people come to identify with the climate movement and engage in its direct action wing. Second, we explore how climate activists maintain hope in the context of what may appear as insurmountable challenges. Third, we discuss how participants interpret the role of direct action in securing large-scale structural shifts to address climate crisis.

\section{Researching Climate Activism}

Within social movement studies there is a long-running theoretical debate about the relative importance of instrumental versus expressive social action. Should social movements be seen as means to an end, or as an end in themselves? More directly, is it more important to study 
how social movements mobilise as against why? (Polletta \& Jasper 2001). With climate action movements, research reveals a strong instrumental theme, centring on the rhetoricreality gap in climate policy (Hall \& Taplin 2008). This affirms a 'political opportunities' model of social movement mobilisation where movements are interpreted as rational actors responding to institutional failure (Tarrow 1996; 1998). At the same time, there can be a strong expressive dimension to climate action, as a form of ethical action. Here climate action can be an end in itself, an intrinsic defence of ethical values in the face of climate injustice (Connor, Freeman \& Higginbotham 2009). However, neither side of this dualism provides an adequate account of social action. This is particularly the case for climate action as played out through Climate Camps. These mobilisations explicitly combine instrumental and expressive dimensions, and activists themselves combine intellectual understanding and affective outrage in their accounts of praxis.

In the Project reported-on here we have focused on the 'direct action' wing of climate agency, where activists directly protest against proposed carbon-intensive facilities to dramatise the requirement for alternatives (see the following section on Climate Camp protest events). There is a long international lineage of direct action environmental protest, that this approach draws on (Klandermans \& Staggenborg 2002; Meyer 2005). We have engaged with a small number of broadly representative participants in these direct action events in Australia, seeking to intensively engage and reflect with them on questions of climate agency. Over two years we interviewed participants at first seeking to understand key moments in the movement, but ultimately were swept up in the ebb and flow of the movement itself. We, also, ourselves, became involved in planning and carrying out direct actions, both as participants, and as researchers, with our double role known to the participants. As such, during the research process we found ourselves drawn into larger dilemmas, or political tensions concerning individual and collective agency that can also be a source of creativity (Maddison \& Scalmer 2006). Interviews were undertaken by Rebecca Pearse, the project research assistant, who is also a member of Friends of the Earth (FoE) Sydney. James Goodman and Stuart Rosewarne also participated in key direct action events, and have written materials for participating organisations.

As an exercise in participant observation, we wanted to ensure, as far as possible, that our accounts would create a fine-grained record of engagement with activist perspectives. In terms of the interview schedule, twenty-five participants were interviewed between two and 
four times over a period of two years. Interviews occurred before, during and after direct action events in order to bring into play both involvement and reflection. Of an original 16 participants in 2008, 3 declined follow-up interviews in 2009. An additional 9 participants were interviewed in 2009 at Climate Camp events in Helensburgh and Melbourne, with a follow-up interview after. Interviews conducted outside protest locations were held in a location nominated by the interviewee. These locations included public spaces such as parks, cafes and university grounds. Others were interviewed at work, at a university research centre or in their homes.

Recruitment was undertaken via recommendations from the Climate Camp organising collectives, and followed a snowballing technique. As with much sociological research, the task of bringing together a 'representative' group of participants is an imperfect science and relies on the researchers' inside knowledge, nevertheless we still sought to maintain representation across gender, age and background.

As such, we consider the group of twenty five to be largely representative of the portion of the climate movement that organised and attended Climate Camp. All participants identified as being involved in grassroots activism. As outlined in the Appendix, interviewees were associated with various community, political and campaign organisations, and four had been had been part of Climate Camp organising collectives. In terms of regional representation, there is a political-geographic bias toward Sydney-based activism with eleven of the participants from Sydney, with the rest from Newcastle, the Hunter Valley, Brisbane or Melbourne. Six participants were linked to environmental non-governmental organisations, as campaigners or members of action collectives, including three from Friends of the Earth. Of the remaining participants, two were from a socialist organisation, six from student organisations, two from community radio collectives, and one participant each from a Climate Action Group, a local residents group and a solar energy cooperative; one indigenous activist from the Gunai/Kurnai Nation in Victoria was also interviewed. Finally, a Greens Member of Parliament was included in the mix, and two other participants identified as local Greens group members.

In terms of interview structure there were three main aspects: personal biography; climate change; and political strategy. First, participants were questioned about their motivations, initially asked why they were attending the Camps. In follow-up interviews, they were asked 
to account for the full trajectory of their activism, and were prompted to tell the 'longer story' behind their participation in the movement. The second aspect relates to how interviewees understand climate change. They were questioned about the causes of climate change, solutions and its severity. Following from this, participants were asked if, and where hope figured in their philosophy of praxis. Third, the interviews posed questions of political strategy. Specifically, the participants discussed the role of collective mobilisation, the politics of 'direct action' (civil disobedience), and more generally the interviewer and interviewee broached questions of how social and political change happens.

The interviews were audio recorded and transcribed, and approximately two-thirds of the interviews were captured on video. This article reports on the interviews using the video material and is deliberately positioned as an experiment in digital ethnography. The video record has allowed us as researchers, and readers, to become more engaged with the interviewees as they wrestle with the difficulties and dilemmas of climate agency. Most important, the video record helps us personalise the accounts: rather than appearing as an abstracted written account, the video material embeds the record, more closely involving us in the embodied experience of climate agency.

The insights, dilemmas and tensions expressed by participants guide the analysis we offer of climate agency. It is an attempt to deploy the digital artefacts of the research process videoed interview material - to deepen engagement with and thereby help shed light on the question of climate agency. In each section we preface the discussion with excerpts from interviews conducted between 2008 and early 2010. There are four videos included in total. One early product from the Project was a short video of activists discussing climate camp which was used for the 2009 Climate Camp website at Helensburgh. It now appears here, in the next section looking at climate camps. The video was a relatively uncritical piece explicitly geared toward event promotion. By contrast the three video sequences we offer in the remainder of this paper seek to explore more critically the dilemmas faced by this movement across the period we interviewed participants.

Cutting the video data into dialogical sequences was a labour-intensive and at times fraught task. Only the authors of this paper have had access to the full body of video material, and we are responsible for making judgements about which interview moments to place into the 
videos presented here. The video excerpts linked to this paper and the transcripts discussed in the paper itself merely dip into the more than thirty hours of footage. As such the account here is by no means exhaustive and the interpretations reflect our concerns as participants and researchers, as much as the concerns of the interviewees. There is full consent from participants both for the use of the video material and the text; participants gave a specific permission to use the material for this article, in addition to the release form signed when first participating in the research.

\section{Direct action Climate Camps in Australia Video: Climate Camp, promotion video http://vimeo.com/15857974 ${ }^{1}$}

Climate camp is a form of strategic direct action geared to movement building. Camps are spatial interventions mounted as close as possible to the physical site of large-scale carbon emissions. The Camps create a temporary community that combines workshops on how to address climate issues with a series of direct actions against expanding fossil fuel installations. As such, they create ideological power as counter-sites, designed to unmask and contest plans to expand carbon-intensive infrastructures and industries (Chatterton \& Pickerill 2010; Griggs \& Howarth 2004; Newell 2008; Seel \& Plows 2000).

As a genre of climate protest Climate Camps first emerged in the UK, which has now seen several camps, at Drax power station in 2006, Heathrow airport in 2007, Kingsnorth power station in 2008, the European Climate Exchange in London in 2009, and also in 2009 at the UK's biggest coal fired power stations at Ratcliffe-on-Soar in Nottingham, and, finally, at the Royal Bank of Scotland in Edinburgh in 2010. The Camps create a temporary community that combines workshops on how to address climate issues with a series of direct actions against expanding fossil fuel installations (Plows 2008; Saunders \& Price 2009). The Climate Camp model has been taken up in a more than twenty mostly Northern countries around the world, including in Australia: Australia's first climate camp was held in Newcastle, the world's largest coal port, in 2008; in 2009 another three camps were held in Australia, and a further 15 worldwide.

\footnotetext{
${ }^{1}$ Donated to Climate Camp in 2009 from Climate Action Research Project footage. Video editing by Justin Harvey and Rebecca Pearse.
} 
The 2008 camp in Australia highlighted the impact of coal mining, both for export and for local energy production. Given the proposed expansion of the coal industry, with a new coal loader planned for Newcastle, as well as more than twenty new mines proposed for the Hunter region, the key demand of the camp was simply for 'no new coal'. The camp was explicitly geared to building a mass social movement on climate change, and thus sought to establish new links between participants, and to increase people's confidence that they could themselves intervene in public debates, and mount effective action to target key perpetrators such as the coal industry. For this research project, we attended the 2008 climate camp, and also two camps in 2009, one in Victoria at the Hazelwood power station, and the other at Helensburgh in NSW, at Australia’s oldest commercial coal mine.

The pictures below are intended to give the reader a sense of the scale and nature of public protest in the three Climate Camp events we attended in Australia. The camps are at first glance are quite mundane looking spaces - a few hundred people camping in a public space, often in trying weather. After workshops, collective decision making and everyday camp provisioning, the participant numbers build and the final day of the Camps sees the groups launch into a public protest. The images illustrate the various modes of participation undertaken by climate activists.

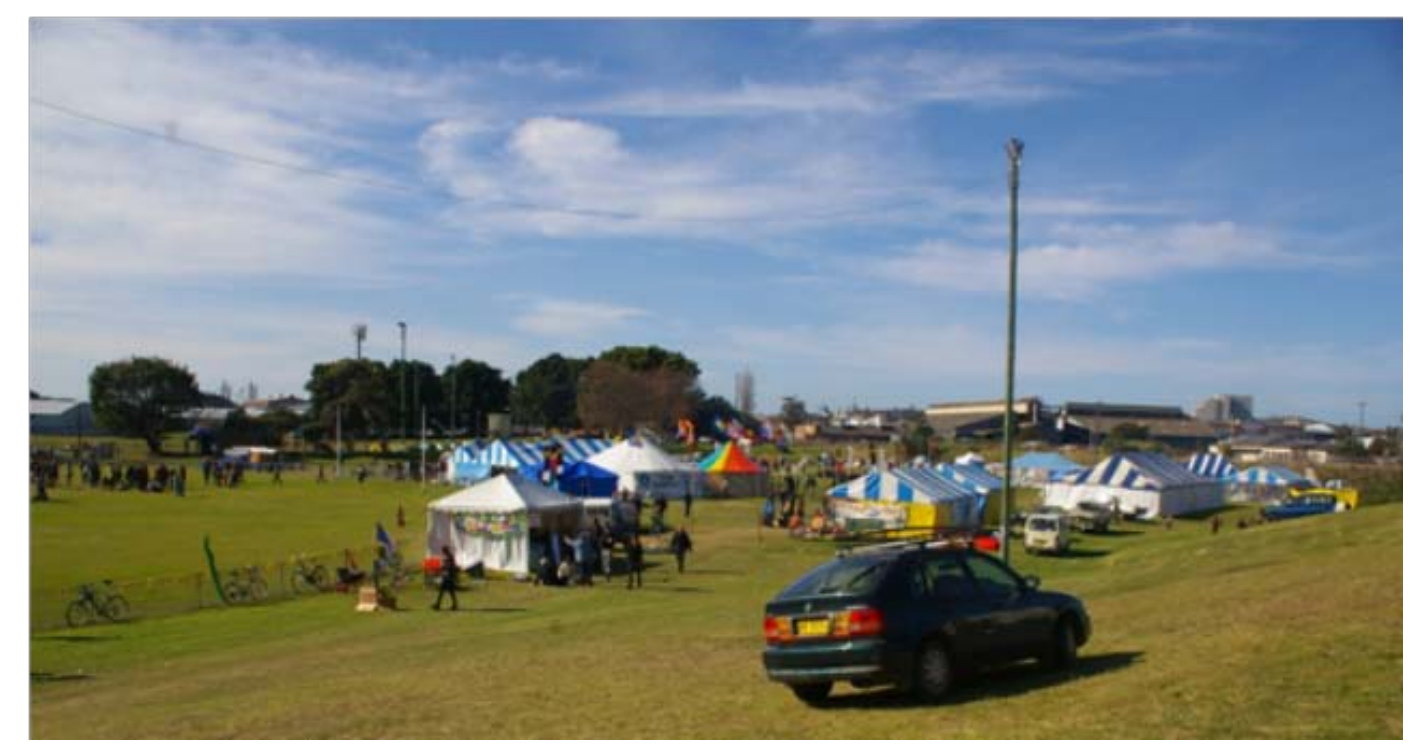

Climate Camp Newcastle, July 2008, Photo source: Climate Camp Newcastle Organising Collective, photographer unknown. 


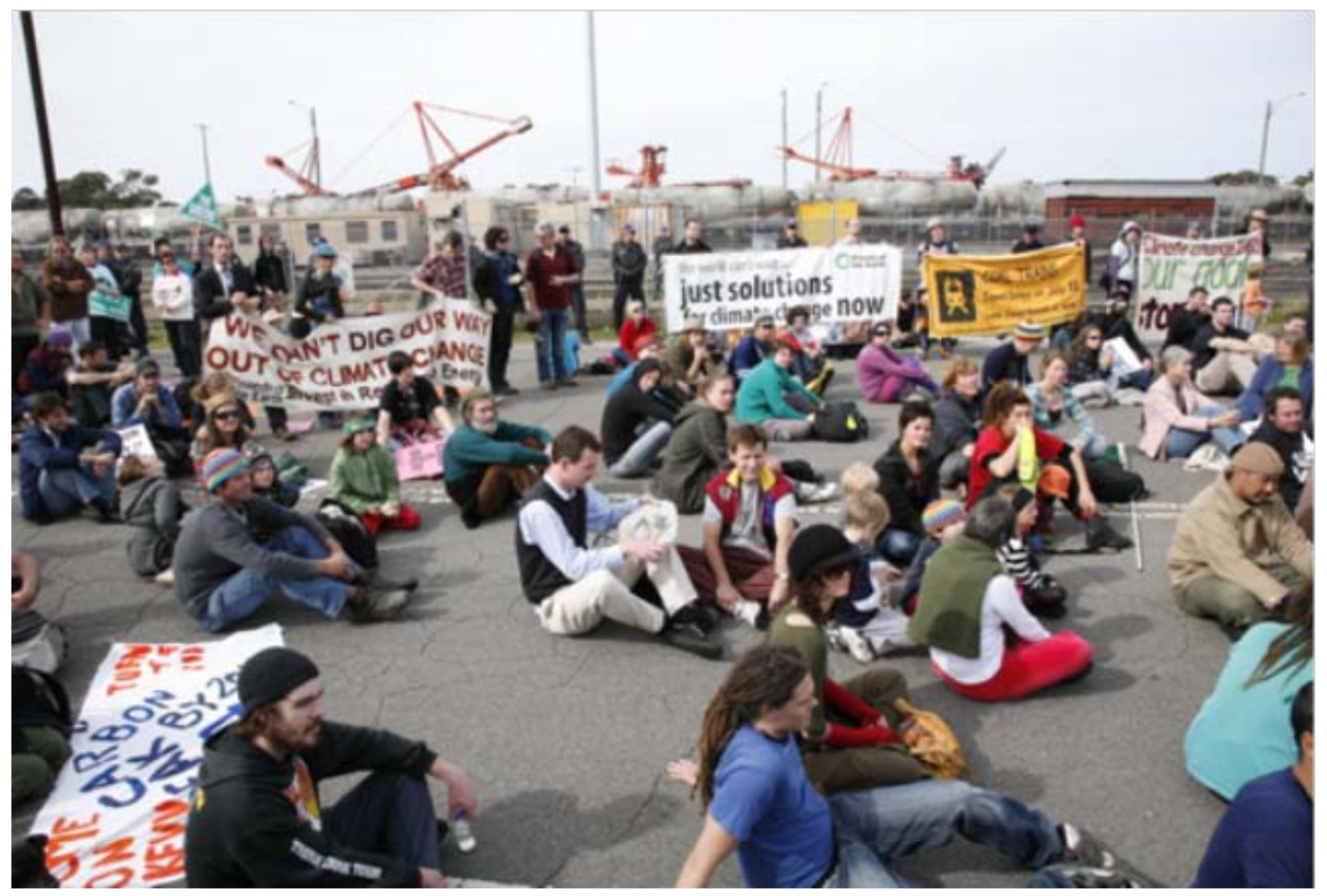

A moment's silence at the final mass rally, Climate Camp, Newcastle July 2008 Photo source: Climate Camp Newcastle Organising Collective, photographer unknown.

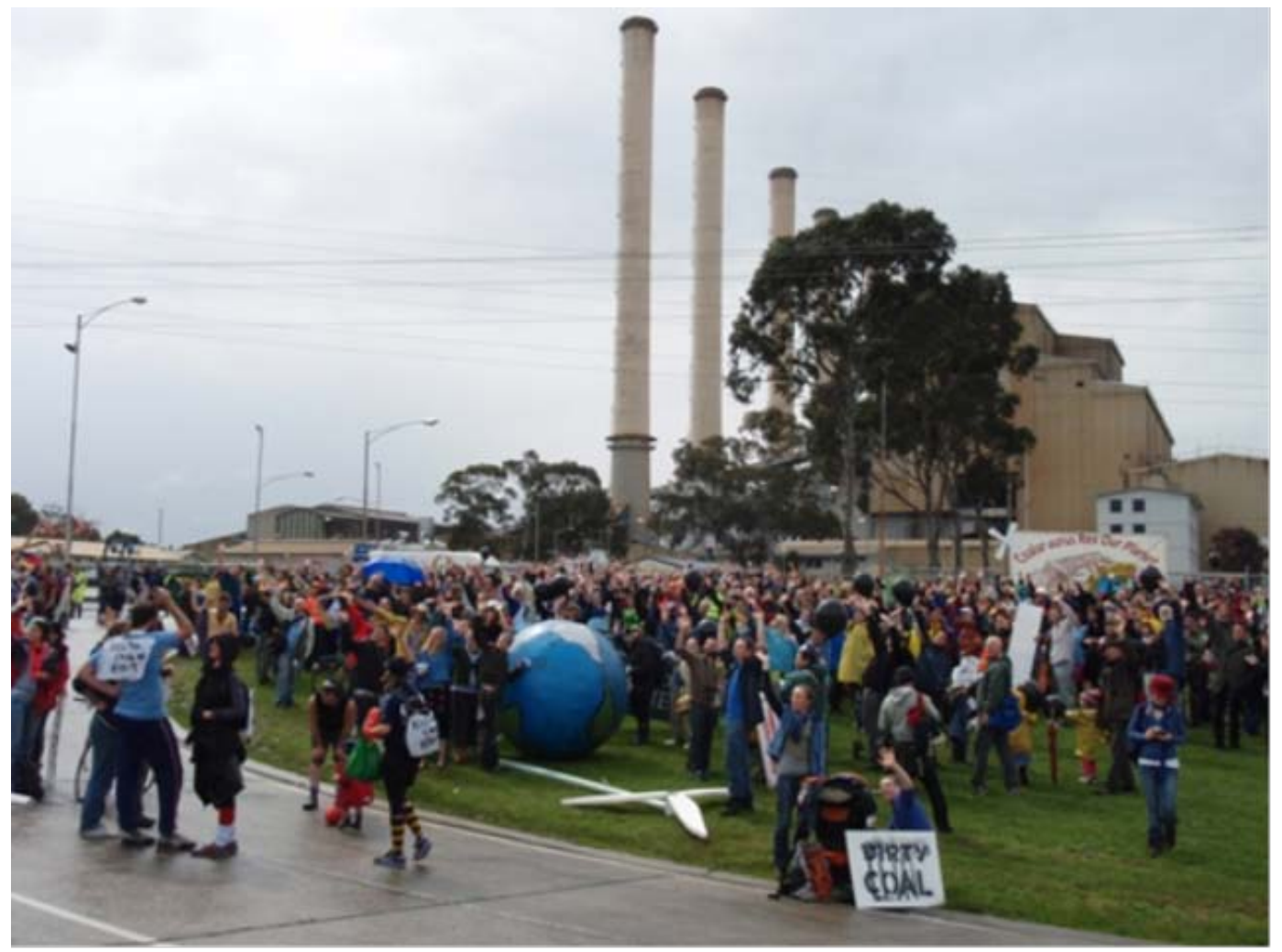

Day of action, Switch Off Hazelwood, Victoria, September 2009, Photo source: James Hitchcock 


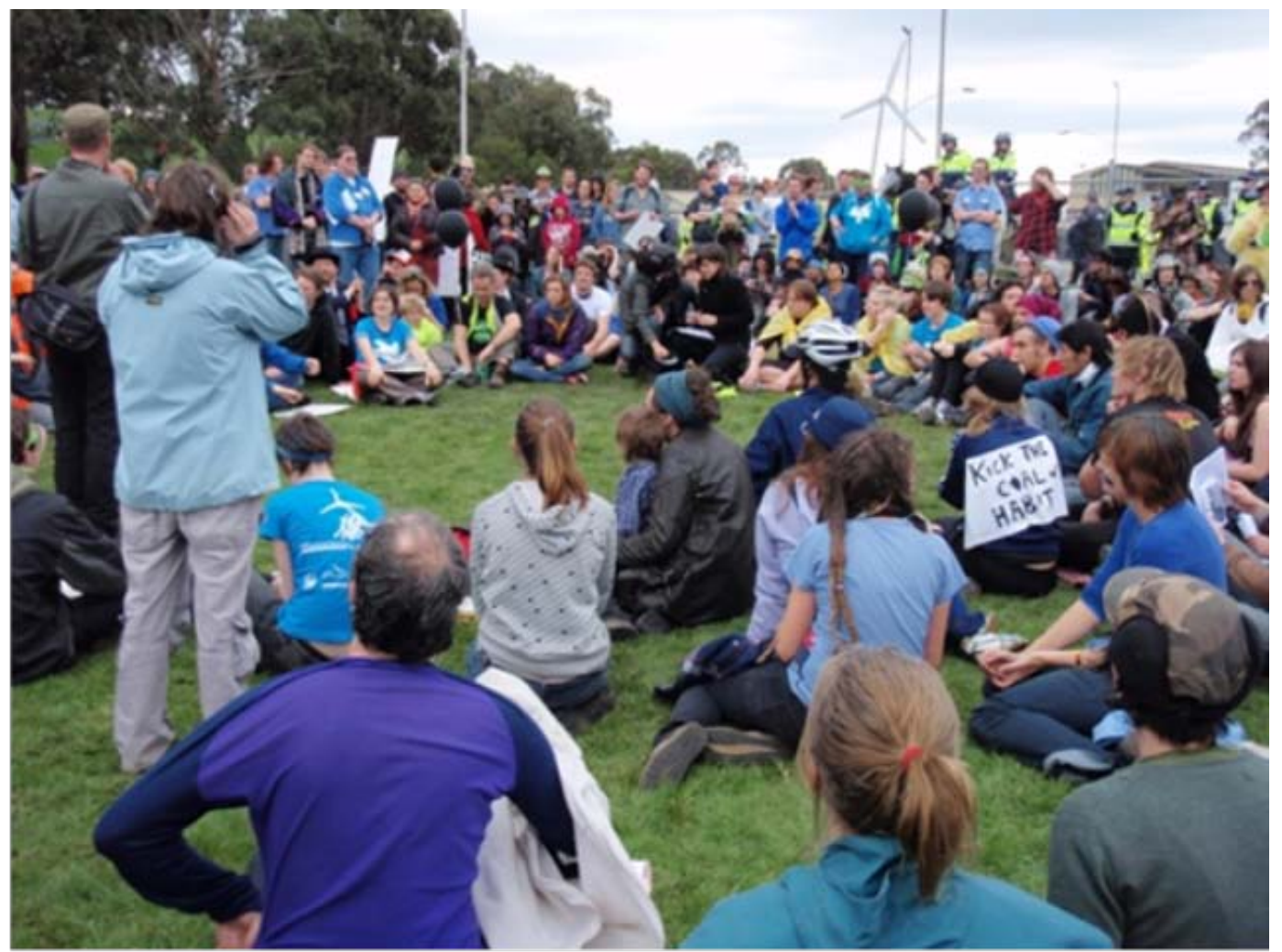

A spokescouncil at Switch Off Hazelwood, Victoria, September 2009

Photo source: James Hitchcock

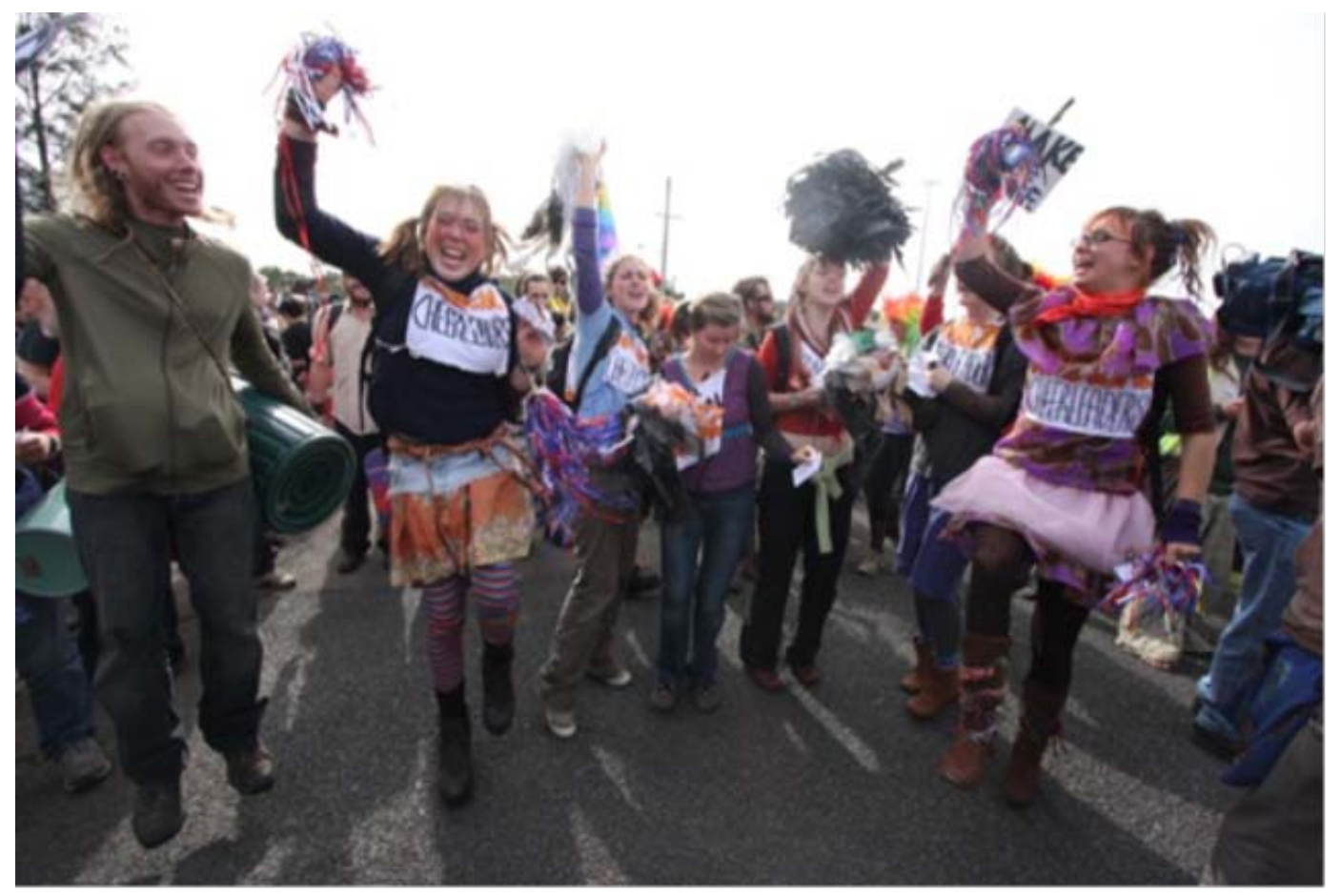

Radical cheerleaders, Climate Camp Newcastle, July 2008

Photo source: Climate Camp Newcastle Organising Collective, photographer unknown. 


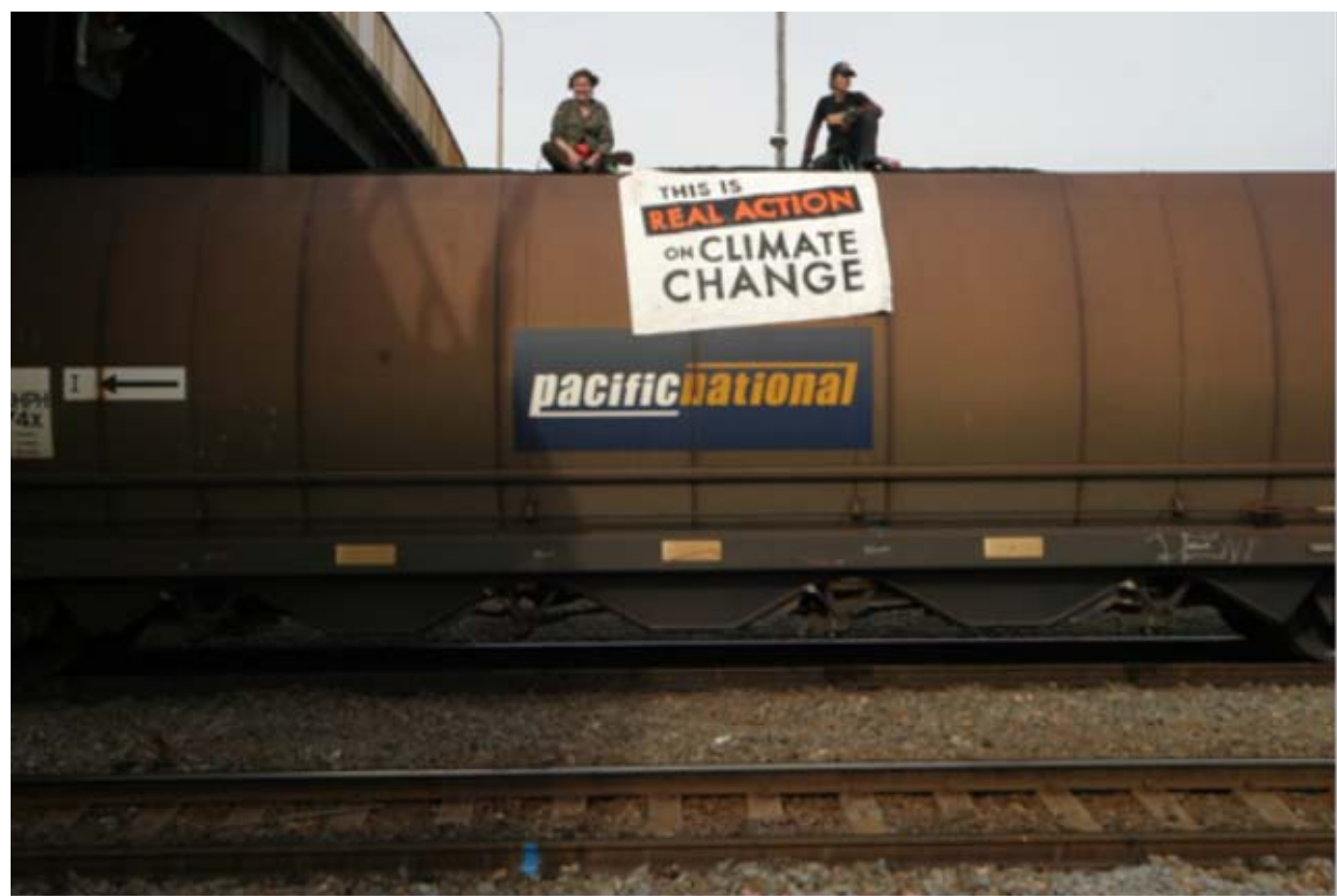

Direct action at Climate Camp Newcastle, July 2008

Photo source: Climate Camp Newcastle Organising Collective, photographer unknown.

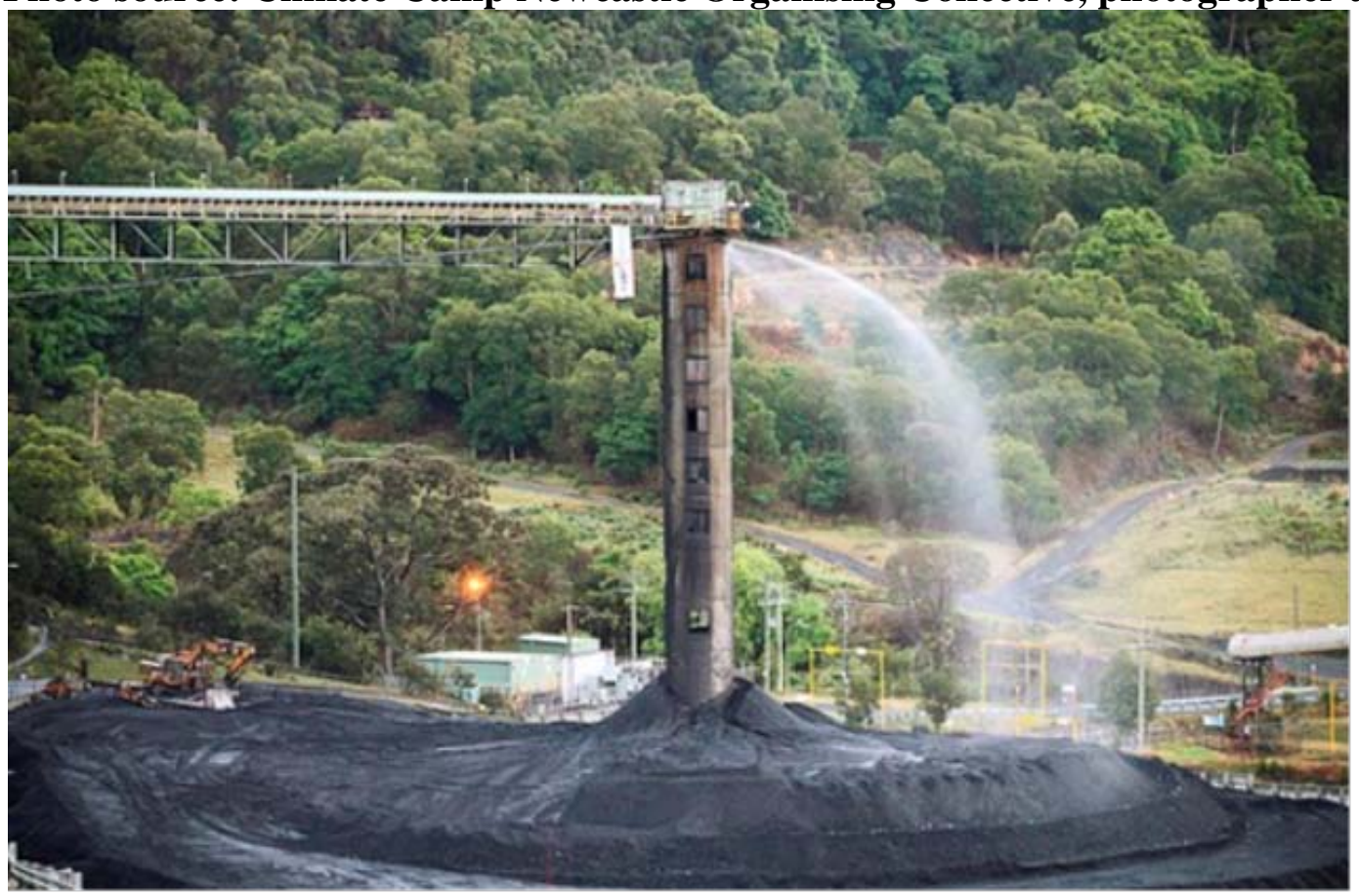

Direct action at Dendrobium coal mine, October 2009, Photo source: Climate Camp Helensburgh organising collective

Organisers of climate camps have put special emphasis on three elements: the process of maintaining the camp, as itself an exercise in collective action; the creation of spaces for reflection and debate on climate issues and how to address them, and the planning and mounting of direct actions against climate change perpetrators. 
Active engagement with making the camp happen, the creation of collective structures to meet practical needs, as well as define the collective priorities, were key aspects of involvement (Osofsky \& Levit 2008). Decision-making structures for the 2008 Australian camp for instance rested on a decentralised 'neighbourhood' structure, with zones of the camp allocated to specific regions or specific groups, who would each plan their own actions. Bringing participants together in 'neighbourhoods' provided a common point of connection for individuals from similar geographic origins, to promote inclusivity and a means for engaging people in a sense of common purpose. Each neighbourhood would send representatives to a consensus-based 'spokes council' which would then coordinate activities for the camp as a whole. These decentralised consensus-based structures were aimed at both maximising a sense of safety, and of direct democratic involvement.

A second aspect was involvement in workshops and debates. These were also an important aspect of the UK climate camps, with over 200 sessions planned for the 2008 Kingsnorth camp in the UK. The involvement of public intellectuals, and the invitation to engage in debate at the camp, signalled an openness to differing viewpoints, and offered an entry-point for those not already involved with climate action. Some of the workshops centred on developing a deeper understanding of the process of climate change - its causes and outcomes - others were focused on debating strategy, in terms of climate policy, and in terms of movement agendas, as well as to transfer campaign skills.

A final aspect was involvement in planning and undertaking direct action. The spatial politics of the camp sets the stage for these interventions, as its location defines the target for direct action (Doherty 2002; Schlosberg 2009). A stream of workshops focused on skills for direct action, including building collective capacity across the groups, such as through the rehearsal of actions, the creation of collective physical capacities, such as non-violent responses to policing, and in simple activities such as capacity to scale fences. In addition, there were 'neighbourhood'-based discussions on kinds of direct action, along with the formation of camp-wide direct action groupings. At the camps, deliberation on direct action was decentralised into cross-camp groupings, defined by level of risk, from non-arrestable actions, such as a march along an approved route, to more physically-challenging and 
arrestable actions. In this way, participants could both choose what suited them, participate in debates about how to mount the actions, and then to participate in them.

Across these three aspects the camps create an immersive experience. Whilst politically marginal and episodic, the camps can be seen as a laboratory for climate action, offering a generative politics prefiguring the possibilities of paradigm shift towards a low-carbon future. As such, the architecture of Climate Camp provided a framework for engaging individuals to recast the terrain on which political ambitions can be progressed. As a social process, climate camp provides a social and organisational space that draws individuals out of what might be their personal frustration with the dominant politics of the times, and what might otherwise be a suffocating malaise, to give voice to understandings and possibilities that come from discussing and sharing this frustration, and acting on it. The Camp is designed to enable personal transformation for those frustrated by the failure of established political channels to formulate any meaningful policies to address the ever-increasing production of greenhouse gases, to marshal people's energies and to concentrate these collective energies to contest our growing reliance on fossil fuels.

As such, the camp is an intensive experience, an expressive moment that comes with all the limitations this entails. It is an oppositional formation, defined against mainstream environmental non-governmental organisations, which are more concerned with policy as against mobilisation, as well as against government policy. It is necessarily short-lived and centred on symbolic action to raise consciousness, and never likely to produce immediate successes in terms of directly reducing emissions. Its contribution is much more ephemeral, resting in the realm of ecological subjectivity, generated from these embodied experiential (McDonald 2006). The camps create a sense of community enlivened through sharing knowledge about the challenge of climate change, and for discussing ways of moving forward as an inclusive process. The camp's architecture actively engages the subject, indeed requires this engagement, drawing on the different and varied capacities, or competencies, to reflect on how to engender a collective consciousness and politics to contest the dominant paradigm.

The project explores this direct action politics of climate change. As such it seeks to answer Giddens' claim that 'we have no politics of climate change' (Giddens 2009, p. 4). We argue 
this movement ignites a politics calling forth different, more radical and engaged forms of politics that contrast with established institutional practices, and that contest those practices that have been so crucial to feeding the sense of impotence that lie at the heart of our collective frustration. It is a politics that is essentially dialectical in character, founded on reflexive engagements, and designed to inspire transformative action. Climate Camp, we contend, makes concrete what Guattari sought to encapsulate in the notion of ecosophy - a process of social liberation through ecological awareness that projects political will of reinvigorated subjects, in this case of the Climate Change community (2005, p. 14).

The discussion that follows centres on three themed reflections on the reflexivity embedded in the individual and collective articulations of climate activist praxis. We begin each section with an exploration of the issues led by participants, albeit necessarily framed within our own analytic and personal reflections. Each section is prefaced with a series of extracts drawn from the videoed interviews, to offer a means of contextualising the written material.

\section{Trajectories of activism}

\section{Video: Activist Trajectories video, http://vimeo.com/15838650 ${ }^{2}$}

Attendance at the Climate Camps was an important moment in each participant's mobilisation; and indeed in the development of this movement. In this first section we recount three longitudinal aspects of mobilisation: becoming aware of injustice, establishing personal commitment, and sustaining ongoing reflection. In the stories of becoming aware and committing to act we understand the participants to be relating a process of immersion into new epistemologies and collectivities (often not initially the climate movement). Meanwhile, the process of mobilisation also entails ongoing critical and strategic reflection. Chris Breen's (2009) reflection in the video on the countless conversations that build into activist subjectivity is instructive. In fact the entire sequence in this first video explores the relational elements of mobilisation. Far from being linear, accounts of mobilisation illustrate a dialectical relationship between establishing sustained commitment and periods of more distanced individual and collective inquiry. This section pivots on the interpersonal, cognitive and affective exchanges that underpin individual mobilisation processes.

\footnotetext{
${ }^{2}$ Participants in order of appearance: Lee Rhiannon, John Hepburn, Rachel Woods, David Burgess, Jasmine Ali, Jenny Curtis, Kristy Walters, Angie, Chris Breen, Peter Kennedy, Graham Brown and Anon\#. Video editing by Sarah Mace-Dennis and Rebecca Pearse.
} 
Individuals vary in the extent to which they are embedded in the groups and networks that underpin social movement participation (Stryker 2000). Embedding occurs over time, though not necessarily in a reliably incremental manner. In participant's accounts of their mobilisation they relate an infiltration of social action into the everyday experiences, albeit in differing ways and to varying degrees (Melucci 1992). As is typical of participants in mass civil disobedience demonstrations, most of the 25 activists interviewed were considerably involved in one or more environmental organisations or autonomous collectives. In the context of follow-up interviews, participants had varying orientations on the identity of activism. Asking participants to account for their trajectory into and experiences of social movements often led participants to reflect on the identity of activist. There was significant ambivalence about the term, and the constraints of defining oneself as 'an activist'. Nonetheless activist as noun, or activism as verb, captures the nature of political identity expressed by this group.

As has been the case with the alter-globalisation movement, climate activists navigate various forms of collectivity on an individuated basis (McDonald 2002). All participants presented multi-causal accounts of their activism, often citing early life connections to nature, family and friends as well as contact with social and environmental issues across time. The paths they described were unruly, both in the telling, and undoubtedly in the experience. Narratives enlisted by participants were internally dynamic, both gradual and punctuated by transformatory moments, linear and disjointed (McKechnie \& Körner 2009). Expressions of awakening, or moral shock figured as moments of disjuncture in participant's accounts of mobilisation, as both starting points and forks in the road toward activism (Hunt \& Benford 1994; Jasper \& Poulsen 1995). These were moments in which the participant relates an event or exchange that crystallises or compels new analysis or understanding of an issue. Jasmine Ali's (2009) account of the 'open political fight' on a university campus and its effect on her politicisation is expressed with gusto, giving a sense of the almost instantaneous depth of political engagement possible via student activism. By contrast other accounts such as Kristy Walter’s (2009) summation of most people’s ‘journey’ into activism imply an incremental, almost linear and commonsense process of immersion. In effect, both modes of narrative and affect seem to hold insights into the process of mobilisation. 
Jenny Curtis' account of her participation in the climate movement reflects this. She is a founding member of one of Australia's approximately 80 active local Climate Action Groups that were established from 2005. These groups are often populated by people mobilised for the first time, or in a much more intense way than previously. She remembered having an 'environmental conscience’ by virtue of her enjoyment of bush walking and completing a degree in Landscape Architecture, but noted 'I never bought the ticket and blockaded down in Tassie or never really stepped up into a major activist thing... I just didn't touch me that much that I needed to get more active' (Curtis 2008). We pick up on her story in the video when she notes that not until 2006 with her children a little older did she join members in her community in forming Climate Change Balmain-Rozelle. In 2006 it was a friend and fellow Climate Action Group member that provided her with links between the coal industry and climate change.

She was really well informed and was saying to the wider group "Let's write letters, because they've just approved another mine". And I'm thinking "But this is climate change, what are we talking about coal mines for?". And I didn't get that, and then after talking to her and finding out $40 \%$ of our greenhouse gas emissions are produced by coal fired power and all those things, it was like "Oh my god!". I just couldn't believe it. I thought "Why don't I know about this?”... I mean everybody needs to know about this, and that's terrible. (Curtis 2008)

Moral shocks figure in participant's stories to explain shifts in thinking, feeling and occasionally a new life trajectory. In the latter half of the video, former Hunter Valley coal miner Graham Brown recounts his decision to leave the coal industry, which in turn propelled a course further into the struggle against coal and climate change. Graham has been a long time trade union activist. Over the past thirty years he has seen the coal industry dramatically alter the Hunter Valley landscape, affecting agriculture, air, water systems and communities. In recent years he has worked on the Anvil Hill campaign posed against Centennial Coal's bid to create an open-cut coal mine at Wybong in the Upper Hunter Valley NSW. He has been prolific in this engagement with coal and climate campaigns, working with the Greens, Greenpeace, Rising Tide, Socialist organisations and more. In this video excerpt he is relating a moment in his vacation to Chile. Sitting with him is his long time friend and coal miner Peter Kennedy.

The spatial dimensions of Graham's story capture both the dilemmas and possibilities built into the climate crisis. Mobilisation spans a range of affective, cognitive and instrumental 
dimensions (Hosseini 2006; McDonald 2006; Melucci 1992; Melucci 1996a). It is a process over time as well as place-dependent, reflecting the history and context of mobilisation (Calhoun 1993). The encounters described by activists illustrate a shift in subjectivity underway as a result of advancing ecological crises such as climate change. Beneath the surface of this totalising problem is our planetary interdependence, which in turn creates new frontiers for human consciousness and action (Melucci 1996b, p. 58).

On the one hand, we see a translocal connection created by the causes and effects of industrial emissions. But on the other, climate change seems to prise the development divide further apart. In Graham’s words:

And now we see the future prospect of our climate with the major dry period that ended about 18 months ago. That is by anyone's knowledge created by the burning of coal. That's the cause of it; coal fired power stations and the use of coal and fossil fuels. We've got to stop that, collectively as a nation, as a state, as a local area and globally. We've got to stop that for my kids, for their kids and for your kids and for everyone's kids, for the bloke in South America. We've got to stop it. (Brown 2008)

Interestingly, stories such as Graham’s do not create a simple logical link between action and outcome, and do not specify agents and agency. They do not engage with the outcome they point to (climate action), but in the moral meaning of events which precede lead to it (Polletta 1998). Graham's interest in the movement is clearly not the product of purely instrumental reason. Personal involvement in the struggle for climate justice is often in the first instance an affective reaction to the situation facing humanity; over time the ebb and flow of personal and collective reflection sees individuals gaining a perspective on how to sustain their activism. The personal trajectories bring climate activists to a form of hope through direct action and mobilisation.

\section{Hope in action}

\section{Video: Hope in action, http://vimeo.com/15839593 ${ }^{3}$}

'I think if we don't win there's no future for anyone. So there's nothing to gained by giving up... You would want to think that you tried. And I suppose that there's various levels of dangerous, catastrophic, irreversible climate change. So every time you do

\footnotetext{
${ }^{3}$ Participants in order of appearance: Emma Brindal, Robbie Thorpe, Kate Campbell, Anne Hodgson, Chris Breen, Libby King, Anon*, John Hepburn, David Burgess, Kristy Walters and Lee Rhiannon. Video editing by Sarah Mace-Dennis and Rebecca Pearse.
} 
anything, you win, it's just a pity that you're probably not going to win enough [laughs].' (Wells 2008)

There is a general consensus across commentators on climate action that people need hope in order to take action (Caldicott 2009; Diesendorf 2009; Flannery 2010). But the problem is that dangerous climate change is already with us, and there is little to hope for in terms of avoiding runaway climate change. This compounds already existing challenges to sustaining activism across the lifespan (King 2004, 2006). In this context, some climate campaigners argue the climate movement has to deliberately accentuate the positive: if we want a movement we must use the language of hope. We arrive at what may be called 'strategic climate action', a position that represses the reality and welcomes every climate initiative, from changing a light bulb to carbon trading, as a positive step no matter how inadequate.

In broaching the issue of hope with interviewees what we have found is that climate activists, and through them movements, are producing their own foundations and motivations for action. Out of this, rather than false hopes, we are seeing an emerging model of moral action. The individual stories that describe how the participants in Climate Camp have been carried onto this charged terrain display how they have been moved by the frustration and despair with the failure of the party political parliamentary process to address the challenge of climate change, while stirred by the hope and inspiration that comes from joining with others to explore ways to confront the challenge of climate change. This is a story of individual responsibility being aroused, discussed and knowledges shared, to ferment an interest in how to begin reframing our place within the ecological world, and to formulate a different form of politics designed to expose the stasis characterised by a hegemonic preoccupation with carbon-intensive with economic growth. However, as we follow the personal and political consequences of these trajectories, we have uncovered more questions than answers.

Climate science is the key starting point. With it, activists speak of being 'immobilised by fear', overwhelmed by the urgency and magnitude of the problem, of losing their sense of agency and descending into 'climate depression'. People speak of lapsing into bouts of despair, especially intense where it is personified in younger generations. Ann Hodgson, member of Rising Tide Newcastle says in the video 'I have nightmares thinking about my young grandchildren, thinking about what their world will be like when they're my age' (Hodgson 2008). 
Anger is directed at carbon-intensive perpetrators, and their defenders. There are many accounts of engaging with non-activists and encountering a range of avoidance strategies, from outright denial, to strategic and deliberate hopelessness, to self-conscious ambivalence. Several of the activists spoke of how they have to channel anger. One put it as follows: 'The whole yeah, laziness and acceptance of people is infuriating for me. So I'm like I said, I've got to try and keep it in check otherwise it would really overwhelm me to a destructive point' (Jen 2008).

Beyond mobilisation, many stress the opportunities embedded in climate crisis. Activists talk passionately about ecological sufficiency, post-consumerism, re-localisation and community mobilisation, as necessary elements and key outcomes of the crisis. These new possibilities can become realities by force of circumstance. Or, as one interviewee put it: 'I don't think we've even had this kind of challenge before. Or this opportunity to radically restructure the entire way we do things' (Anonymous\# 2008). This balancing between despair and hope, with a dose of anger, is signalled in people's motivation. Amongst this group of activists, at least, there was only one person who said they would not be involved in the movement if they didn't believe that dangerous climate change could be prevented.

A recurrent theme from all participants was that hopes come from engagement with the movement. Emma Brindal remarked: 'I think just being involved in campaigning and activism in itself gives hope; and being surrounded by and working with other people who are really dedicated to creating a better world; that inspires me with hope constantly' (Brindal 2008). Lee Rhiannon broadens this position in the video when she conceives of collective political engagement a success in itself (Rhiannon 2008).

The rest voiced an absolute certainty in the necessity for mobilisation, regardless of whether climate change can be addressed. Their action is grounded in something less contingent that says, as one put it: 'this is the right thing to do'. Here climate mobilisation becomes an intrinsic necessity, and end in itself, regardless of anticipated outcome. What has become clear from the research is that while moral action sustains activist identity, it is not associated with autonomy, rather with universality. Climate mobilisation affirms self-respect and human dignity, but it does not enact a sectional identity, rather it directly produces a universalist humanism. 
Importantly, the moral protest of climate activism is, in principle, universal. With climate change whole populations are made immediately and collectively aware of a world-historical process, creating a global consciousness that politicises carbon pollution as a threat to survival. This is the underlying trajectory of climate change, and the foundation for the moral appeal of climate action. As such, climate action makes a claim to be all-enveloping, a movement that is everywhere, embedded in the emergent universal subjectivity of life under climate change. From this perspective activists can despair at the built-in logic of climate change, and at the same time vest hopes in mass action to create new possibilities. Regardless of whether hopes or fears are realised, climate action remains the right thing to do.

\section{Political strategy and vision}

\section{Video: Political strategy and vision, http://vimeo.com/15854625 ${ }^{4}$}

In my experience the thing that sustains activism and involvement in social movements is community. It's people you know, feeling really supported, feeling really inspired by other people. (Hepburn 2008a)

Nonviolent direct action, directed at challenging the hegemony of the fossil-fuel intensive orthodoxy is one of the key political expressions of the Climate Camp project. Such action draws on the capacities and confidence of individuals working together, on the inspirations that are derived from the communities, and the affinity groups, that help to constitute this political community. It is a dynamic political project that contrasts with the passivity that defines the formal political agenda associated with ecological modernisation discourses.

Direct actions are designed to firstly expose the calamity that is the fossil-fuel dependent industrial undertaking. Equally, however, the direct actions have as a conscious purpose calling a halt to this undertaking. In doing so, the political project confronts capital and the state as the engineers, those immediately profiting from the venture of mining and burning of coal, at the same time as it challenges the dominant politics that underpins this undertaking.

Climate Camp does this through an enduring dialectic between the individual engagement and the collective, one that respects the capacity and the confidence of the individual,

\footnotetext{
${ }^{4}$ Participants in order of first appearance: Maurice Wells, Nicky Ison, Anon*, Anon\#, Chris Breen, Erland Howden, Anon^, Robbie Thorpe and John Hepburn. Video editing by Sarah Mace-Dennis and Rebecca Pearse.
} 
ensuring that they are comfortable with the character of their participation and will not be pressured to move beyond their comfort zones. Yet, it is also a process that constructs community and instils a confidence in individuals as members of communities. This politics of engagement draws on individual participant's capacities to explore the different ways in which the political project can be advanced.

The key feature is communality, as the foundation for creating empowering ideas and how to act on these. The forms of direct action are founded on the competencies that reside within the affinity groups, as this opens up the spaces in which political wills can be exercised. The relative autonomy of the neighbourhood communities and how these are translated into affinity or action groups provides the space for conceiving and articulating ideas for action; the organisation of another layer in the larger community of the Climate Camp, the spokescouncils, provides the forum for these to be discussed, debated and developed in conjunction with the broader community. It is a process that is open and participatory while not constraining of the possibilities for action.

The Climate Camp architecture provides the arena in which individuals engage with others, to learn more about the nature of the ecological crisis and how this knowledge can be marshaled in ways that enable individuals to develop the confidence, confront the sense of impotence, to exercise a competence by joining with others to give expression to the political possibilities. Direct action, through the exercise of nonviolent direct actions, becomes the vehicle for giving expression to dissident sentiments. Civil disobedience actions become one of the few options if the political protest is to be given voice, the means for igniting the collective frustration with the refusal of governments to address the challenge of climate, the failure of traditional institutional political forums to progress initiatives for containing the growth in the exploitation of fossil fuels and generation of greenhouse gas emissions.

Direct action reflects the arousal of individuals' capacity to act, to give life to subjectivity, as a collective production of unpredictable and untamed ‘dissident subjectivities’ (Guattari 2005, p. 14). This is a particularly distinctive and dynamic politics, centring on direct democracy: 
I see direct action in a nutshell as a kind of doing it yourself. Not asking somebody else to do it for you. (Anonymous\# 2008)

Climate Camp contests the received ways of doing politics precisely because it is so personally empowering. It is about the exercise of responsibility and taking control of the political process by moving beyond the established political realm. The forms of direct action are contingent upon the capacities of individuals working with others to peel back the sites that are to be object of their political action. And because this politics engages diversity, there is a multiplicity of possibilities as to how dissidence is projected.

As such, Climate Camp is about orchestrating a new political field, one that is directed towards sustaining the endeavour to bring an end to the fossil-fuel based energy-intensive economy. Non-violent direct action is defined as the necessary vehicle for progressing this ambition because the established political realm is so deeply embedded in the logic of the fossil-fuel based economy:

[direct action] is best thought of, or most powerfully thought of, as a strategy of withdrawing consent from the status quo. And if you think of it as a strategy, then the most powerful thing people can do is to engage in civil disobedience and say 'I'm no longer consenting to the government killing our planet and ruining our future.' (Hepburn 2008b).

Dissonance is the necessary vehicle for confronting the established order, the means for venting the frustration with this order, but also the means for engaging beyond the community of the Climate Camp. Non-violent direct action takes the form of spectacle, exposing the sensitivities of the dominant order to carry an alternative political narrative into the public domain, to extend the reach of a counter-hegemonic project. The spectacle of direct actions provides a springboard for building on this alternative narrative.

[direct action] can like draw people's attention to an issue... seeing successful direct action or even just seeing people have a go at something... is a really important aspect of education (Anonymous*2008).

The spectacle of civil disobedience, of non-violent direct actions, does not, of course, guarantee that the political message will be taken up among the broader population. The 
actions will be resisted. The civil disobedience will be maligned, and the progression of the political project will be likely face setbacks and falter from time to time. But the strength of the project does not rest on the outcomes of singular actions. It is an exercise in charting an alternative future that rests on arousing and sustaining the vibrancy of human subjectivity, of an ecological sensibility that requires continual contesting of the established order. It is a movement that is "a call for the revival of individual confidence as a social force" (Guattari 2005, p. 15). As such it is one that is founded on the reflexivity of the subjects who go into the making of Climate Camp, and herein lies the strength of Climate Camp as a process that is personally empowering and one founded on creating this other community.

Needless to say this political project is not without its tensions and contradictions. While the spokes-council architecture in bringing different communities together provides the means to accommodate different tendencies and the diversity of strategic visions, the architecture is not necessarily a successful means of assuaging manoeuvring by some organised political tendencies to dictate particular political actions or initiatives. Within the Climate Summit deliberations, the concern with entrisme has been publicly articulated.

Similarly, the ability of Climate Camp to engage the broader community is necessarily a delicate process because the occupation of spaces as sites for launching non-violent direct actions, such as occurred with the Helensburgh Camp, can arouse the antipathy of members of the local community. Local communities may understandably be resistant to an invasion of those whom they may regard as interlopers, if not trouble makers, and seemingly posing a possible threat to the local order. The Climate Camp organisers were quite conscious of this possibility, and concerted efforts were made to introduce the local community to the concerns of the proposed Camp in the weeks leading up to the actual event. But notwithstanding the organisation of community-based forums and extensive leafleting of residents with a view to opening a dialogue and inviting them to participate, there was what seemed like a wellorganised reproach of the culminating Climate Camp event. As activists proceeded down Helensburgh's main street to the entrance to the Peabody coal mine, they confronted not just a police formation blocking the entrance, but a large assembly of locals, some displaying banners protesting the action, and others, mostly teenagers, who took great delight in the occasion launching eggs and tomatoes in the direction of activists. 
The Helensburgh Climate Camp action had spawned a counter spectacle, and while this might be interpreted as a symbol of the failure of the Climate Camp action to progress one of its objectives, that is of engaging the local community, the fact that local residents were excited into action should, we suggest, be read as a positive because their action meant that they too were having to reflect on the challenge of climate change.

This does, however, prompt the need to reflect on the more challenging question that confronts the political agenda, and this is how to maintain the momentum of the movement. This is not just an issue extending the reach of the political landscape that is occupied in the ambition of engaging the broader community. It is also a matter of maintaining the dynamism of the broad coalition of social forces, and of sustaining the energy that is so essential to this. It also highlights the necessity for preserving the openness and inclusiveness of the movement, for institutionalising the centrality of reflexivity, and avoiding the movement becoming the prisoner of particular political tendencies to ensure the continuing evolution of the dynamism and innovative nature of the enterprise.

\section{Conclusions}

In this discussion we have asked how can we produce accounts that actively involve the reader in the experience of climate action, whilst at the same time, generating insights into how climate agency may be strengthened. Through these dual focal points, we have sought to elicit reflexivity vis-à-vis engagement with movement participants, through videoed interviews, transcribed recordings, and through our own participation.

Our research shows how activists are producing a new language of moral protest in the face of a profound historical conjuncture. As such, they are actively generating the political tools for addressing the crisis. As the historian Dipesh Chakrabarty (2009) has argued, we are living through a confrontation between the history of the species, as expressed in climate science, and the history of humanity. How we are to bridge the two, and exercise human agency in the face of a species-wide crisis, is the key question for the climate movement. Climate activists are self-consciously engaged in this intellectual process of generating new visions and new models for action in the context of climate change. In apprehending the profound clash of histories, activists are finding ways of moving beyond fatalism, and are creating new foundations for mobilisation. 


\section{Appendix}

Participants in the study

\begin{tabular}{|c|c|c|}
\hline & Name & Organisation \\
\hline \multirow{3}{*}{ 串 } & Anon.\# & Social justice organisation, Sydney \\
\hline & Emma Brindal & Friends of the Earth Australia/Brisbane \\
\hline & Erland Howden & Nature Conservation Council NSW, Sydney \\
\hline \multirow{12}{*}{ 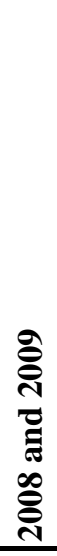 } & Anon.* & Various autonomous collectives, Newcastle \\
\hline & Ann and Ian Hodgson & Rising Tide, N ewcastle \\
\hline & Graham Brown & Miscellaneous - works with the Greens, Greenpeace and socialist organisations, Musselbrook \\
\hline & Jasmine Ali & Solidarity, Sydney \\
\hline & Jen & Mayfield East Residents Group, Newcastle \\
\hline & Jenny Curtis & Climate Change Balmain Rozelle, Sydney \\
\hline & John Hepburn & Greenpeace, Newcastle/Sydney \\
\hline & Lee Rhiannon & NSW Greens, Sydney \\
\hline & Libby King & USyd student environment collective, Third Degree Radio Show, Sydney \\
\hline & Maurice Wells & Solar Energy Coope rative, Sydney \\
\hline & Nicky Ison & Australian Student Environment Network, S ydney \\
\hline & Peter Kennedy & Coal miner, Musselbrook \\
\hline \multirow{9}{*}{ 옹 } & Angie & UNSW student environment collective, Sydney \\
\hline & Chris Breen & Solidarity, Melbourne \\
\hline & Dave Burgess & The Total Environment Centre, Sydney \\
\hline & Kate Campbell & Various, Melbourne \\
\hline & Kristy Walters & Australian Student Environment Network, 6 D egrees/FoE Brisbane \\
\hline & Lance Batey & Resident, Wollar NSW \\
\hline & Rachel Woods & UOW student environment collective, Wollongong \\
\hline & Robbie Thorpe & Gunai/Kurnai Nation; 3CR, Melbourne \\
\hline & Anon.^ & Friends of the Earth, Melbourne \\
\hline
\end{tabular}

\section{References}

Ali, J. 2009, Interview, 17 November, with Rebecca Pearse, Sydney.

Anonymous\# 2008, Interview, 08 July, with Rebecca Pearse, Newcastle.

Anonymous* 2008, Interview, 08 July, with Rebecca Pearse, Newcastle.

Beck, U. 1992, Risk society: Towards a new modernity, Sage, London.

Bourdieu, P. \& Wacquant, L.J.D. 1992, An Invitation to Reflexive Sociology, University of Chicago Press, Chicago.

Breen, C. 2009, Interview, 12 September, with Rebecca Pearse, Switch Off Hazelwood,

Hazelwood, Victoria.

Brindal, E. 2008, Interview, 09 October, with Rebecca Pearse, By phone.

Brown, G. 2008, Interview, 11 October, with Rebecca Pearse, Muswellbrook.

Caldicott, H. 2009, If You Love This Planet: A Plan to Save the Earth, W.W. Norton, New York.

Calhoun, C. 1993, '"New social movements" of the early nineteenth century', Social Science History, vol. 17, no. 3, pp. 385-427.

Chakrabarty, D. 2009, 'The climate of history: Four theses', Critical Inquiry, vol. 35, no.

Winter, pp. 197-222. 
Chatterton, P. \& Pickerill, J. 2010, 'Everyday activism and transitions towards post-capitalist worlds', Transactions of the institute of British Geographers, vol. 35, no. 4, pp. 475-490.

Connor, L., Freeman, S. \& Higginbotham, N. 2009, 'Not just a coalmine: Shifting grounds of community opposition to coal mining in Southeastern Australia', Ethnos, vol. 74, no. 4, pp. 490-513.

Curtis, J. 2008, Interview, 13 October, with Rebecca Pearse, Rozelle.

Diesendorf, M. 2009, Climate Action: A Campaign Manual for Greenhouse Solutions, UNSW Press, Sydney.

Doherty, B. 2002, Ideas and Actions in the Green Movement, Routledge, London.

Elias, N. 1956, 'Problems of involvement and detachment', British Journal of Sociology, vol. 7, no. 3, pp. 226-252.

Elias, N. 2007, Involvement and Detachment, 1897-1990, Collected Works, Vol. 8, University College Dublin Press, Dublin.

Flannery, T. 2010, Here On Earth: A Sustainable Future, The Text Publishing, Melbourne.

Giddens, A. 2009, The Politics of Climate Change, Polity Press, Cambridge.

Griggs, S. \& Howarth, D. 2004, 'A transformative political campaign? The new rhetoric of protest against airport expansion in the UK', Journal of Political Ideologies, vol. 9, no. 2, pp. 181-201.

Guattari, F. 2005, The Three Ecologies, Athlone Press, London.

Hall, N.L. \& Taplin, R. 2008, 'Room for climate advocates in a coal-focused economy? NGO influence on Australian climate policy', Australian Journal of Social Issues, vol. 43, no. 3, pp. 359-379.

Hepburn, J. 2008a, Interview, 07 July, with Rebecca Pearse, Newcastle.

Hepburn, J. 2008b, Interview, 17 October, with Rebecca Pearse, Sydney.

Hodgson, A. 2008, Interview, 07 July, with Rebecca Pearse, Maitland.

Hosseini, S.A.H. 2006, 'Beyond practical dilemmas and conceptual reductions: the emergence of an 'accommodative consciousness' in the alternative globalisation movement', Portal Journal of Multidisciplinary International Studies, vol. 3, no. 1, pp. $1-27$.

Hunt, S. \& Benford, R. 1994, 'Identity talk in the peace and justice movement', Journal of Contemporary Ethnography, vol. 22, no. 4, pp. 488-517.

Jasper, J.M. \& Poulsen, J.D. 1995, 'Recruiting strangers and friends: Moral shocks and social networks in animal rights and anti-nuclear protests', Social Problems, vol. 42, no. 4, pp. 492-512.

Jen 2008, Interview, 23 October, with Rebecca Pearse, Newcastle.

Johnston, J. \& Goodman, J. 2006, 'Hope and activism in the ivory tower: Freiean lessons for critical globalisation research', Globalisations, vol. 3, no. 1, pp. 9-30.

Juris, J.S. 2008, 'Performing politics: Image, embodiment, and affective solidarity during anti-corporate globalisation protests', Ethnography, vol. 9, no. 1, pp. 61-97.

King, D. 2004, 'Operationalising Melucci: Metamorphosis and passion in the negotiation of activists' multiple identities', Mobilization: An International Quarterly, vol. 9, no. 1, pp. 73-92. 
King, D. 2006, 'Activists and emotional reflexivity: Toward Touraine's subject as social movement', Sociology, vol. 40, no. 5, pp. 873-891.

Klandermans, B. \& Staggenborg, S. 2002, 'Introduction', in B. Klandermans \& S. Staggenborg (eds), Methods of Social Movement Research, University of Minnesota Press, Minneapolis, pp. xi-xx.

Low, N. 2010, 'Power of persuasian creates critical mass for climate action', The Age, 6 September, viewed 27 September 2010 $<$ http://www.theage.com.au/opinion/politics/power-of-persuasion-creates-critical-massfor-climate-action-20100905-14vxh.html>.

Maddison, S. \& Scalmer, S. 2006, Activist Wisdom: Practical Knowledge and Creative Tension in Social Movements, UNSW Press, Sydney.

McDonald, K. 2002, 'From solidarity to fluidarity: Social movements beyond 'collective identity' - the case of globalization conflicts', Social Movement Studies, vol. 1, no. 2, pp. $109-128$.

McDonald, K. 2006, Global Movements: Action and Culture, Blackwell, Oxford.

McKechnie, R. \& Körner, B. 2009, 'Unruly narratives: Discovering the active self', in D. Robinson, P. Fisher, TraceyYeado-Lee, S.J. Robinson \& P. Woodcock (eds), Narrative and Memory and Identities, University of Huddersfield, Huddersfield.

Melucci, A. 1992, 'Liberation or Meaning? Social Movements, Culture and Democracy', Development and Change, vol. 23, no. 3, pp. 43-77.

Melucci, A. 1996a, Challenging Codes: Collective Action in the Information Age, Cambridge University Press, Cambridge.

Melucci, A. 1996b, The Playing Self: Person and Meaning in the Planetary Society, Cambridge University Press, Cambridge.

Meyer, D.S. 2005, 'Social movements and public policy: Eggs, chicken and theory', in D.S. Meyer, V. Jenness \& H.M. Ingram (eds), Routing the Opposition: Social Movements, Public Policy, and Democracy, University Of Minnesota Press, Minneapolis.

Mills, C.W. 1959/2000, The sociological imagination, Oxford University Press, Oxford.

Newell, P. 2008, 'Civil society, corporate accountability and the politics of climate change', Global Environmental Politics, vol. 8, no. 3, pp. 122-153.

Osofsky, H. \& Levit, J. 2008, 'The scale of networks? Local climate change coalitions', Chicago Journal of International Law, vol. 8, pp. 409-436.

Plows, A. 2008, 'Towards an analysis of the 'success' of UK Green Protests', British Politics, vol. 3, no. 1, pp. 92-109.

Polletta, F. 1998, "'It Was like a Fever..." Narrative and identity in social protest', Social Problems, vol. 45, no. 2, pp. 137-159.

Polletta, F. \& Jasper, J.M. 2001, 'Collective identity and social movements', Annual Review of Sociology, vol. 27, pp. 283-305.

Rhiannon, L. 2008, Interview, 16 October, with Rebecca Pearse, Sydney.

Riach, K. 2009, 'Exploring participant-centred reflexivity in the research interview', Sociology, vol. 43, no. 2, pp. 356-370.

Rojek, C. 1986, 'Problems of involvement and detachment in the writings of Norbert Elias', British Journal of Sociology, vol. 37, no. 4, pp. 584-596. 
Saunders, C. \& Price, S. 2009, 'One person's eu-topia, another's hell: Climate Camp as a heterotopia', Environmental Politics, vol. 18, no. 1, pp. 117-122.

Schlosberg, D. 2009, 'Capacity and capabilities: A response to the greenhouse development rights framework', Ethics, Place and Environment, vol. 12, no. 3, pp. 287-290.

Seel, B. \& Plows, A. 2000, 'Coming live and direct: Strategies of Earth First!', in B. Seel, M. Paterson \& B. Doherty (eds), Direct Action in British environmentalism, Routledge, Oxon, pp. 112-132.

Steier, F.E. 1991, Research and Reflexivity, Sage, London.

Stryker, S. 2000, 'Identity competition: Key to differential social moevment participation?', in S. Stryker, T.J. Owens \& R.W. White (eds), Self, Identity and Social Movements, University of Minneapolis Press, Minneapolis.

Tarrow, S. 1996, 'States and opportunities: The political structuring of social movements', in D. McAdam, J. McCarthy \& M.N. Zald (eds), Comparative Perspectives on Social Movements: Political Opportunities, Mobilizing Structures, and Cultural Framings, Cambridge University Press, Cambridge, pp. 41-61.

Tarrow, S. 1998, Power in Movement: Social Movements and Contentious Politics, Cambridge University Press, Cambridge.

Touraine, A. 1995, Critique of Modernity, Blackwell, Cambridge.

Walters, K. 2009, Interview, 10 October, with Rebecca Pearse, Climate Camp, Helensburgh NSW.

Wells, M. 2008, Interview, 20 October, with Rebecca Pearse, Marrickville. 